\title{
Identification of Hypertensive Youth
}

\section{Duncan Buchan*, Lon Kilgore, Fergal Grace and Julien S Baker}

Institute of Clinical Exercise and Health Science, School of Science, Faculty of Science and Technology, University of the West of Scotland, Hamilton, Lanarkshire, Scotland

Blood pressure (BP) is well established as a powerful, independent risk factor for cardio-vascular disease (CVD). Throughout the globe, it is estimated that 1 in every 4 adults suffer from hypertension which easily makes this risk factor the leading cause of death in the Western World [1]. Within youth, hypertension rates are also increasing with some suggesting that the growing obesity levels throughout the globe are the likeliest contributor [2]. Within the European Union it is estimated that a minimum of $21.8 \%$ of youths aged between 5 and 18 years suffer from hypertension [3]. Although once considered a rare condition in childhood, hypertension is now common in both children and adolescents [4] and has been shown to track within hypertensive children from adolescence into adulthood [5,6]. Numerous factors have been suggested as significant predictors of hypertension, and include; level of education, socio-economic status, diet, dyslipidemia, inflammation, poor physical activity and cardiorespiratory fitness levels [7]. Unsurprisingly, recent attention has focused upon enhancing our understanding of the prevalence of hypertension in children and adolescents, particularly in mind of current obesity rates throughout the globe.

Whilst data regarding this issue has been available, only recently has the European Society of Hypertension provided any guidance on the management and diagnosis of hypertension for children and adolescents [8]. Given the lack of large longitudinal intervention studies involving European youth, the authors of that document, understandably, were unable to provide any evidence based thresholds for those children most at risk of elevated BP readings. As such, the comprehensive normative $\mathrm{BP}$ values derived from children and adolescents in the US which provides BP percentiles for age, gender and height [9] are often used in youth investigations and to categorise hypertensive individuals. Nonetheless, the National High Blood Pressure Education Program (NHBPEP) recommendations are derived from a representative sample of US children and adolescents and may not be appropriate for European youth. The norms produced by the NHBPEP were derived from nearly 70,000 American youth aged between 1 and 17 years who participated in a variety of studies during the 1970s and 1980s. During a similar period BP was measured among 28,043 youth participants from six North-West European countries [10]. When the data was pooled together, the findings demonstrated that age, gender, and height-adjusted percentiles of systolic/diastolic BP were, on average, $6 / 3 \mathrm{~mm} \mathrm{Hg}$ higher in the European cohort than in the American cohort. It seems that these findings alone may limit the practicality of accurately identifying European youth who may be at risk of hypertension when relying upon the NHBPEP norms. Furthermore, given the rising obesity epidemic seen in the last three decades, and the frequently reported positive association between weight status and BP [11], it seems prudent to question the feasibility of using the norms provided by the NHBPEP to identify at risk individuals.

Although it is questionable to utilize a single BP level to define hypertension since children and adolescents are continually developing as they age, hypertension thresholds have been provided by the International Diabetes Foundation (IDF) as part of their classification of the metabolic syndrome in youths [12]. This it seems has stemmed from the inconsistent thresholds currently available and indeed the need for a rationalized definition that will avoid the confusion and conflict of opinion that stems from the multiple thresholds currently available. With regards to BP thresholds, the authors provide simple absolute values to identify at risk individuals. While they attempt to provide differing thresholds for those under and over 16 years of age, the lack of definitive research findings involving youth participants precludes the authors from providing support for such criteria.

It is generally believed that $\mathrm{BP}$ in youth follow the pattern of obesity increases seen over the past two decades, however, until population appropriate longitudinal data documenting such trends is available it will remain unclear whether this association actually exists. Consequently, relying upon dated BP classification criteria from non-specific populations to identify children at risk of developing hypertension appears flawed and may lead to misidentification and mismanagement of hypertensive youth.

\section{References}

1. World Health Organization, Preventing chronic disease: a vital investment 2005, World Health Organization http://www.who.int/chp/chronic_disease_ report/full_report.pdf. Accessed 17th May 2011: Geneva, Switzerland.

2. Urbina E, Alpert BC, Flynn J, Haymann L, Harshfield AG, et al. (2008)Ambulatory Blood Pressure Monitoring in Children And Adolescents: Recommendations for Standard Assessment: a scientific statement from the American Heart Association Atherosclerosis, Hypertension, and Obesity in Youth Committee of the council on cardiovascular disease in the young and the council for high blood pressure research. Hypertension 52: 433-451.

3. Lobstein T, Jackson-Leach R (2006) Estimated burden of paediatric obesity and co-morbidities in Europe. Part 2. Numbers of children with indicators of obesity-related disease. Int J Pediatr Obes 1: 33-41.

4. Sorof JM, Lai DL, Turner J, et al. (2004) Overweight, Ethnicity, and the Prevalence of Hypertension in School-aged Children. Pediatrics 113: 475-482.

5. McCarron P, Smith GD, Okasha M, McEwen J, et al. (2000) Blood pressure in young adulthood and mortality from cardiovascular disease. Lancet 355: 14301431.

6. Mahoney LT, Burns TL, Stanford W, Thompson BH, Witt JD, et al. (1996) Coronary risk factors measured in childhood and young adult life are associated with coronary artery calcification in young adults: the Muscatine Study. J Am Coll Cardiol 27: 277-284

7. Lloyd-Jones D, Adams RJ, Brown TM, Carnethon M, Dai S, et al. (2010) Heart disease and stroke statistics--2010 update: a report from the American Heart Association. Circulation 121: e46-e215.

8. Lurbe E, Cifkova R, Cruickshank JK, Dillon MJ, Ferreira I, et al. (2009) Management of high blood pressure in children and adolescents: recommendations of the European Society of Hypertension. J Hypertens 27: 1719-1742.

*Corresponding author: Dr. Duncan Buchan, Institute of Clinical Exercise and Health Science, School of Science, Faculty of Science and Technology, University of the West of Scotland, Hamilton, Lanarkshire, ML3 OJB, Scotland, E-mail: duncan.buchan@uws.ac.uk

Received September 06, 2012; Accepted September 06, 2012; Published September 10, 2012

Citation: Buchan D, Kilgore L, Grace F, Baker JS (2012) Identification of Hypertensive Youth. J Sports Med Doping Stud 2:e124. doi:10.4172/21610673.1000e124

Copyright: @ 2012 Buchan D, et al. This is an open-access article distributed under the terms of the Creative Commons Attribution License, which permits unrestricted use, distribution, and reproduction in any medium, provided the original author and source are credited. 
Citation: Buchan D, Kilgore L, Grace F, Baker JS (2012) Identification of Hypertensive Youth. J Sports Med Doping Stud 2:e124. doi:10.4172/21610673.1000 e124

9. NHBPEP, National High Blood Pressure Education Program Working Group on High Blood Pressure in Children and Adolescents. The Fourth Report on the Diagnosis, Evaluation, and Treatment of High Blood Pressure in Children And Adolescents. Pediatrics (2004) 114: 555-576.

10. de Man SA, André JL, Bachmann H, Grobbee DE, Ibsen KK, et al. (1991) Blood pressure in childhood: pooled findings of six European studies. J Hypertens 9: 109-114
11. Williams DP, Going SB, Lohman TG, Harsha DW, Srinivasan SR, et al. (1992) Body fatness and risk for elevated blood pressure, total cholesterol, and serum lipoprotein ratios in children and adolescents. Am J Public Health 82: 358-363.

12. Zimmet P, Alberti KG, Kaufman F, Tajima N, Silink M, et al. (2007) The metabolic syndrome in children and adolescents - an IDF consensus report. Pediatr Diabetes 8: 299-306. 